\title{
FEATURES OF LEARNING FOREIGN LANGUAGES AT SCHOOL UNDER THE CONDITIONS OF INCLUSIVE EDUCATION
}

\section{CARACTERÍSTICAS DA APRENDIZAGEM DE LÍNGUAS ESTRANGEIRAS NA ESCOLA EM CONDIÇÕES DE EDUCAÇÃO INCLUSIVA}

\section{CARACTERÍSTICAS DEL APRENDIZAJE DE LENGUAS EXTRANJERAS EN LA ESCUELA EN CONDICIONES DE EDUCACIÓN INCLUSIVA.}

\author{
Chernysh V. Valentyna ${ }^{1}$ \\ Navolska I. Halyna ${ }^{2}$ \\ Rusavska O. Olha ${ }^{3}$ \\ Ryabokin Nataliia ${ }^{4}$ \\ Paustovska V. Marianna ${ }^{5}$
}

\begin{abstract}
Pedagogical experience testifies to the positive introduction of the practice of inclusive education of pupils with special educational needs into the educational process, in particular during learning foreign languages. The purpose of the academic paper is to reveal the features of learning foreign languages at school under the conditions of an inclusive education. The following methods have been used in the scientific article, namely: the methods of theoretical analysis, the method of decomposition analysis, the method of induction, the method of analogy, the method of comparison, the method of scientific abstraction, the method of description, the method of observation, the method of measurement, the method of modeling. It has been found that pupils with special educational needs are actively involved in the educational process of educational institutions, including schools. It has been established that the rights of people with disabilities, including pupils with special educational needs, are governed by the provisions of the Convention on the Rights of Persons with Disabilities and World-Readiness Standards for Learning Languages. It has been established that in the United Kingdom, in particular in England and Wales, there is a program which stipulates that all students, in particular those with special educational needs, should take a foreign language course. It has been proven that there is a special course in Scotland, which provides opportunities for pupils with special educational needs to learn a modern language while studying at the secondary school. It has been established that an active policy of attracting pupils with special educational needs to study at secondary schools has been operating in Finland. It has been found that in Germany, the law establishes rules for the inclusion of students with special educational needs in the general education system. The practice of
\end{abstract}

\footnotetext{
${ }^{1}$ Kyiv National Linguistic University. Kyiv, Ukraine.

2 Ternopil Volodymyr Hnatiuk National Pedagogical University.Ternopil, Ukraine.

${ }^{3}$ National university "Odessa Maritime Academy". Odessa, Ukraine.

${ }^{4}$ Poltava Institute of Economics and Law. Poltava, Ukraine.

${ }^{5}$ Kyiv National Linguistic University. Kyiv, Ukraine.
} 
inclusive education in the USA has revealed that during the 2017/2018 academic year, almost 7 million persons received special education between the ages of 3 and 21 .

Keywords: Inclusive education, pupils (students) with special educational needs, learning foreign languages.

Resumo: A experiência pedagógica atesta a introdução positiva da prática da educação inclusiva de alunos com necessidades educativas especiais no processo educativo, em particular durante a aprendizagem de línguas estrangeiras. $O$ objetivo do artigo acadêmico é revelar as características da aprendizagem de línguas estrangeiras na escola em condições de uma educação inclusiva. Os seguintes métodos foram usados no artigo científico, a saber: os métodos de análise teórica, o método de análise de decomposição, o método de indução, o método de analogia, o método de comparação, o método de abstração científica, o método de descrição, o método de observação, o método de medição, o método de modelagem. Verificou-se que os alunos com necessidades educacionais especiais estão ativamente envolvidos no processo educacional das instituições de ensino, incluindo escolas. Foi estabelecido que os direitos das pessoas com deficiência, incluindo alunos com necessidades educacionais especiais, são regidos pelas disposições da Convenção sobre os Direitos das Pessoas com Deficiência e Padrões de Prontidão Mundial para a Aprendizagem de Línguas. Foi estabelecido que no Reino Unido, em particular na Inglaterra e no País de Gales, existe um programa que estipula que todos os alunos, em particular os com necessidades educativas especiais, devem fazer um curso de línguas estrangeiras. Está provado que existe um curso especial na Escócia, que oferece oportunidades para alunos com necessidades educacionais especiais aprenderem uma língua moderna enquanto estudam na escola secundária. Foi estabelecido que uma política ativa de atrair alunos com necessidades educacionais especiais para estudar em escolas secundárias está em vigor na Finlândia. Verificou-se que, na Alemanha, a lei estabelece regras para a inclusão de alunos com necessidades educacionais especiais no sistema educacional geral. A prática da educação inclusiva nos EUA revelou que durante o ano letivo 2017/2018, quase 7 milhões de pessoas receberam educação especial com idades entre 3 e 21 anos.

Palabras clave: Educação inclusiva, alunos (alunos) com necessidades educacionais especiais, aprendizagem de línguas estrangeiras.

Resumen: La experiencia pedagógica atestigua la introducción positiva de la práctica de la educación inclusiva de alumnos con necesidades educativas especiales en el proceso educativo, en particular durante el aprendizaje de lenguas extranjeras. El propósito del trabajo académico es revelar las características del aprendizaje de lenguas extranjeras en la escuela en las condiciones de una educación inclusiva. Los siguientes métodos se han utilizado en el artículo científico, a saber: los métodos de análisis teórico, el método de análisis de descomposición, el método de inducción, el método de analogía, el método de comparación, el método de abstracción científica, el método de descripción, el método de observación, el método de medición, el método de modelado. Se ha descubierto que los alumnos con necesidades educativas especiales participan activamente en el proceso educativo de las instituciones educativas, incluidas las escuelas. Se ha establecido que los derechos de las personas con discapacidad, incluidos los alumnos con necesidades educativas especiales, se rigen por las disposiciones de la Convención sobre los derechos de las personas con discapacidad y las Normas de preparación mundial para el aprendizaje de idiomas. Se ha establecido que en el Reino Unido, en particular en Inglaterra y Gales, existe un programa que estipula que todos los estudiantes, en particular aquellos con necesidades educativas especiales, deben tomar un curso de lengua extranjera. Se ha demostrado que existe un curso especial en Escocia, que brinda oportunidades para que los alumnos con necesidades educativas especiales aprendan un idioma moderno mientras estudian en la escuela secundaria. Se ha establecido que en Finlandia está funcionando una política activa de atraer alumnos con necesidades educativas especiales para que estudien en las escuelas secundarias. Se ha encontrado que en Alemania, la ley establece reglas para la inclusión de estudiantes con necesidades educativas especiales en el sistema educativo general. La práctica de la educación inclusiva en los EE. UU. Ha revelado que durante el año académico 2017/2018, casi 7 millones de personas recibieron educación especial entre las edades de 3 y 21 años. 
Palavras-chave: Grupos de descendência de linhagem familiar, Transmissão intergeracional da educação, Análise de coortes, República Democrática do Congo (RDC), Matriz de transição, Métodos de persistência intergeracional (IGP).

\section{INTRODUCTION}

Current tendencies in school education reform indicate a positive introduction of the practice of inclusive education of pupils with special educational needs into the educational process. As an example, in many countries of the world there is a practice of active involvement of pupils with special educational needs to study at school classrooms with ordinary students, because in accordance with the provisions of international instruments (for instance, the Convention on the Rights of Persons with Disabilities and WorldReadiness Standards for Learning Languages), discrimination against the rights of people with disabilities is prohibited, in particular, this applies to students with special educational needs. With regard to the disciplines that pupils with special educational needs master, foreign languages occupy a significant share in the structure of all disciplines.

In accordance with the above mentioned, the issue of conceptual principles of the educational process, during which foreign languages are studied by students, including pupils with special educational needs at school under the conditions of inclusive education, acquires special relevance in the academic paper).

The purpose of the scientific article is to reveal the features of learning foreign languages at school under the conditions of an inclusive education.

Research objectives having set in the academic paper are as follows:

1) review of the theoretical principles of learning foreign languages at school under the conditions of an inclusive education;

2) analysis of training courses and training programs for teachers to teach foreign languages to students with special educational needs at school;

3) presenting practical experience of learning foreign languages by pupils with special educational needs at school.

\section{LITERATURE REVIEW}

In the course of presenting the results of the research, the viewpoints of scientists should be considered first of all, in particular, to review the literature on solving the issue of learning foreign languages at school under the conditions of an inclusive education.

In view of what follows, Miesera S., DeVries JM, Jungjohann J. and Gebhardt M. (2018), considering the issue of inclusion of students with special educational needs in the educational process in Germany, state that a comprehensive training program should be developed and implemented as a matter of priority, according to which these students will be taught in the future. In addition, the researchers have come to conclusion that the formation of a favorable classroom environment, in particular the improvement of the social-psychological climate in the classroom between ordinary pupils and pupils with special educational needs, is influenced by such teacher's traits as the intention to teach students with special educational needs, attitude to pupils with special educational needs and the effectiveness of teaching material during the education of students with special educational needs (Miesera, S., DeVries, J. M., Jungjohann, J., Gebhardt, M., 2018). 
Mitchell D. (2008) in the course of investigating a number of strategies, offered to teachers for training students with special educational needs, identifies the following key strategies for presenting educational material by teachers under the conditions of inclusive education, namely:

1) a strategy for provision of the inclusive education;

2) a strategy of teaching students with special educational needs based on their inclusion in cooperative groups;

3) a strategy to support school culture and polite treatment towards pupils with special educational needs;

4) a strategy of involving parents in the educational process of students with special educational needs;

5) a strategy of improving the quality of presenting materials to pupils with special educational needs;

6) a strategy of forming a favorable social-psychological climate among students;

7) a strategy of formation of social skills during conducting trainings;

8) a strategy of forming the process of self-regulatory learning;

9) a strategy of application of mnemonics and other tools designed to improve the memorization of educational material into the educational process;

10) a strategy of cognitive behavioral therapy;

11) a strategy of application of auxiliary technologies in educational process;

12) a strategy for creating accessible opportunities and appropriate conditions for teaching students with special educational needs (Mitchell, D., 2008).

Florian L., Young K. and Rouse M. (2010) analyze the features of teachers' training in order to teach pupils with special educational needs under the conditions of an inclusive education in the jurisdiction of the United Kingdom - Scotland. In the course of the investigations conducted, scientists have come to the conclusion that it is necessary to significantly reform pedagogical education with a tendency to prepare teachers for teaching students with special educational needs (Florian, L., Young, K., Rouse, M., 2010).

In addition, Florian L. and Linklater H. (2010) propose to introduce a new training course for teachers to teach pupils with special educational needs. The basic essence of this course should be primarily aimed not at acquiring new knowledge by teachers, but at the ability of teachers to apply their own knowledge to teach pupis with special educational needs (Florian, L., Linklater, H., 2010).

Florian L. (2017) also researches the issue of teachers' education and considers teachers' training in accordance with the conditions of inclusive education. Taking this into consideration, the researcher emphasizes the need to form teachers' qualities to be ready to present educational material to pupils with special educational needs in accordance with the rules of the educational process in inclusive education (Florian, L., 2017).

At the same time, Pokrivcakova S. (2015) in her own research considers the features of the process of teaching students with special educational needs foreign languages, while conducting the investigation on the example of schools in Slovakia. Based on the investigations coducted, the researcher has come to conclusion that the legal framework of this country, as well as the documents adopted by Slovakia in order to ensure appropriate conditions for students with special educational needs, meet international norms and standards set by international institutions and international organizations. Along with this, Pokrivcakova S. 
suggests to use modern educational tools for presenting educational material in the context of learning foreign languages by students with special educational needs in order to improve their learning capabilities, namely:

1) multi-sensory learning, thanks to which all the senses of students with special educational needs function simultaneously, which helps them better learn and understand the material;

2) audiobooks, the use of which in the educational process will make it possible for students with special educational needs to better perceive educational material by simultaneously receiving information due to reading and hearing the text by ear;

3) mnemonic devices, the use of which in the educational process will make it possible for students with special educational needs to better memorize educational material (Pokrivcakova, S., 2015).

McColl H. (2005), considering the interconnection between inclusion and the specifics of foreign language learning, states that it is necessary to develop a special curriculum in order to improve the performance of students with special educational needs towards learning foreign languages. The basic content of the curriculum should take into account the individual qualities and learning needs of pupils with special educational needs. At the same time, McColl $\mathrm{H}$. proves the need to use modern innovative and interactive technologies in the educational process, because thanks to them students with special educational needs can better perceive and assimilate educational material (McColl, H., 2005).

Troeva B. (2016) explores the role of inclusive education in the study of foreign languages. In the course of the investigations conducted, the researcher has identified the following problems that most often arise in the process of learning foreign languages at school under the conditions of an inclusive education, namely:

a) insufficient preparation of school teachers to present educational material to pupils with special educational needs, which reduces the level of their perception of educational material in the context of their acquirement of the discipline;

б) the inner feeling of unpreparedness for teaching students with special educational needs, which often accrues to teachers during the learning process;

B) unwillingness of teachers to teach students with special educational needs, which is contrary to the principle of the right of everyone to receive quality education, including pupils with special educational needs who receive inclusive education (Troeva, B., 2016).

Along with this, Troeva B. in her study also presents the results of a survey of teachers who teach English (the opinion of 26 teachers was interviewed) and other foreign languages (the opinion of 4 teachers was interviewed) in Bulgaria concerning determining their position and attitude towards learning foreign languages by pupils with special educational needs at school. In view of what follows, the scientist has come to the conclusion that teachers who teach students with special educational needs a foreign language (foreign languages) show a relatively restrained attitude towards this process. At the same time, a significant part of teachers do not even resort to searching for specialized methods and recommendations for training pupils with special educational needs in the context of their learning a foreign language (foreign languages) (Troeva, B., 2016).

DeFalco L. (2011) studies the features of staffing a foreign language classroom at school, based on the fact that there will be students with special educational needs there who will receive inclusive education. Following on from, the scientist emphasizes the need for a comprehensive staffing of such classrooms, which will make it possible to overcome the problem of rejection of educational material by students of inclusive classes in the future (DeFalco, L., 2011). 
Medrado B. P., Mello D. and Tonelli J. R. A. (2019) in their work present different practices of inclusive education in the context of foreign language teaching by teachers for students with special educational needs in Brazil. Researchers claim that according to Brazilian legislation, students with special educational needs are directly involved in the learning process. However, according to the results of the assessment of educational practice in inclusive education in Brazil, Medrado B. P., Mello D. and Tonelli J. R. A. state that this process is quite laborious and involves the revision and improvement of public policy in the field of ensuring appropriate learning conditions for pupils with special educational needs (Medrado, B. P., Mello, D., Tonelli, J. R. A., 2019).

MacAskill M. (2016) in his own study considers the features of equal access of students, including pupils with special educational needs, to study foreign languages in Scotland. The scholar argues that modern language education should be improved in accordance with the conditions of inclusive education. This, in turn, will allow teachers better mastering the strategy of learning a foreign language by students with special educational needs and at the same time acquiring practical skills for the educational process (MacAskill, M., 2016).

Based on the investigations of Hildebrandt S. A. (2020), the basics of inclusive education are currently being actively introduced into the practice of foreign language learning. Along with this, the educational process, during which students with special educational needs learn a foreign language, is based on such principles as: 1) the principle of effective teaching the educational material; 2) the principle of free choice of information for learning a foreign language; 3 ) the principle of clarity of instructions for the presenting the educational material; 4) the principle of availability of information at any time; 5) the principle of politeness in correcting mistakes; 6 ) the principle of minimizing physical effort; 7 ) the principle of proper organization of educational space; 8 ) the principle of positive cooperation between a teacher and pupils (Hildebrandt, $S$. A., 2020).

Herewith, Motschenbacher H. (2016) notes that the decisive role in the study of a foreign language by pupils with special educational needs is played by the state of the learning environment, in particular, the example of foreign language classrooms. According to the requirements of international standards and norms governing the conditions of inclusive education, foreign language classrooms, in which students are directly involved in the course of learning a foreign language, should be equipped with modern innovative and interactive technologies (Motschenbacher, H., 2016).

The results of the literature review and the study of the viewpoints of scientists show that the issue of learning foreign languages at school under the conditions of an inclusive education has not been fully explored yet and it requires a comprehensive approach in order to reveal the features of foreign language learning at school in the context of an inclusive education.

\section{METHODS}

In order to achieve the purpose of the academic paper, which centers around outlining the features of foreign language learning at school under the conditions of an inclusive learning environment, and solving the problems set in the article, the following general and special research methods have been used and applied, namely: the method of theoretical analysis and the method of decomposition analysis (to study the theoretical principles of foreign language learning at school under the conditions of an inclusive education), the method of induction (to identify the level of inclusive education based on a review of modern programs, courses, online courses), the method of analogy and the method of comparison (to compare the practice of inclusive education between countries), the method of scientific abstraction and the method of description (to reveal the features of foreign language learning by pupils with special educational needs), the observation 
method, the modeling method and the measurement method (to study the basic trends of the development of an inclusive education in the studied countries).

The methodological basis of the scientific article is based on the following provisions and data, namely: Convention on the Rights of Persons with Disabilities (CRPD) (United Nations, 2016); WorldReadiness Standards for Learning Languages (ACTFL); Global Education Park Finland (Global Education Park Finland, 2017); German education server (German education server, 2019); programs of the British government on the features of mastering a foreign language course by pupils with special educational needs (Wilson, D., 2019); inclusive education programs in Germany (Mainichi, 2019); courses to encourage and organize the training of students with special educational needs in order to learn foreign languages, presented by Hilary McColl's website (Languages without Limits, 2016), SENCO Forum (SENCOFORUM, 2020), FLTeach (FLTeach, 2017), Crearive Education (Creative Education, 2020); special course, according to which the study of the language in Scotland is conducted as one to two ("Language Learning in Scotland: A 1+2 Approach") (Education Scotland. National Improvement Hub, 2020); the program "English As A Second Language (ESL) For Inclusive Education" (The Progressive Teacher, 2020); online course developed and implemented by Oxford University Press (England) (Oxford University Press, 2020); GOV.UK (GOV.UK, 2020); National Center for Education Statistics (National Center for Education Statistics, 2019).

\section{RESULTS}

In the context of inclusive education, pupils with special educational needs are admitted to an educational institution (including school) and this is not affected even by the fact that they have the opportunity or do not have the opportunity to study, that is, are disabled ones. According to the investigations of numerous practitioners, who study in depth the issues of inclusive education, the introduction of a number of advanced innovative and interactive technologies in the educational process can overcome the difficulties of teaching students with special educational needs and increase their learning outcomes.

Consequently, the first stage of the algorithm for revealing the practical principles of learning foreign languages at school under the conditions of an inclusive education is the analysis of the basic trends in inclusive education, for example, in such country as the United Kingdom, forasmuch as this country has a well-developed inclusive education system. This, first of all, will provide an opportunity to highlight information about the current system of inclusive education in highly developed countries, and accordingly, based on the analysis of the data obtained - to identify possible areas for improvement of the existing system of inclusive education. In addition, the practical experience of developing an inclusive education system in the UK can be a demonstrative example for numerous countries that are currently actively involved in the formation and development of inclusive education.

Taking this into consideration, practice shows that the number of pupils with special educational needs, who study at regular schools, is growing every year. The analysis has revealed that in the UK for the $2019 / 2020$ academic year, the percentage of pupils with special educational needs, enrolled in regular schools, increased to 3,3\% against 2,9\% for the 2015/2016 academic year (Table 1). Tendentiously to the dynamics of growth of the share of students with special educational needs, studying at ordinary schools, there was an increase in the level of assistance to such students by the state: in the 2019/2020 academic year, the percentage of assistance increased by 0,6 points compared to the $2015 / 2016$ and $2016 / 2017$ academic years. 
Table 1. Dynamics of pupils with special educational needs in the educational process of schools

\begin{tabular}{|c|c|c|c|c|c|c|c|c|c|c|}
\hline \multirow{2}{*}{$\begin{array}{l}\text { Indicator/ } \\
\text { academic year }\end{array}$} & \multicolumn{2}{|c|}{$2015 / 2016$} & \multicolumn{2}{|c|}{$2016 / 2017$} & \multicolumn{2}{|c|}{$2017 / 2018$} & \multicolumn{2}{|c|}{ 2018/2019 } & \multicolumn{2}{|c|}{$2019 / 2020$} \\
\hline & $\%$ & $\begin{array}{l}\text { relativ } \\
\mathrm{e} \text { to } \\
\text { the } \\
\text { previo } \\
\text { us year }\end{array}$ & $\%$ & $\begin{array}{l}\text { relativ } \\
\mathrm{e} \text { to } \\
\text { the } \\
\text { previo } \\
\text { us year }\end{array}$ & $\%$ & $\begin{array}{l}\text { relativ } \\
\mathrm{e} \text { to } \\
\text { the } \\
\text { previo } \\
\text { us year }\end{array}$ & $\%$ & $\begin{array}{l}\text { relativ } \\
\mathrm{e} \text { to } \\
\text { the } \\
\text { previo } \\
\text { us year }\end{array}$ & $\%$ & $\begin{array}{l}\text { relativ } \\
\mathrm{e} \text { to } \\
\text { the } \\
\text { previo } \\
\text { us year }\end{array}$ \\
\hline $\begin{array}{l}\text { Pupils with } \\
\text { special } \\
\text { educational } \\
\text { needs }\end{array}$ & 2,8 & - & 2,8 & 0 & 2,9 & $+0,1$ & 3,1 & $+0,2$ & 3,3 & $+0,2$ \\
\hline State assistance & 11,6 & - & 11,6 & 0 & 11,7 & $+0,1$ & 11,9 & $+0,2$ & 12,1 & $+0,3$ \\
\hline
\end{tabular}

Source:it has been compiled on the basis of GOV.UK, 2020.

Based on the above mentioned information, it should be noted that there is a clear trend towards increasing the level of inclusive education in the UK. At the same time, there is a gradual annual funding of inclusive learning processes, particularly in schools. Such positive tendencies in inclusive education of the UK could be an impetus for many countries to develop inclusive education.

With regard to the practice of inclusive education in other countries of the world, for instance, in Finland, pupils with special educational needs are also actively involved in education at secondary schools. However, there are cases when students with special educational needs study in special classes or special schools. In order to increase the performance level of pupils with special educational needs, it is necessary to ensure active cooperation not only between teachers and assistants who teach such students, but also with parents and various professionals. Such cooperation will support the special needs of students in the educational process during their mastery of academic disciplines.

In Germany, as an alternative, legislation also lays down rules for the inclusion of pupils with special educational needs in the general education system. In addition, the schooling of pupils with special educational needs in Germany is also regulated by the Convention on the Rights of Persons with Disabilities (CRPD). In accordance with the provisions of the Convention on the Rights of Persons with Disabilities, the German government prevents discrimination against the rights of students with special educational needs by granting them equal rights along with ordinary students to study in educational institutions, including schools.

It is also worth noting that in Germany, more and more cases are being diagnosed recently when children (who, for example, are just enrolled to school) have problems with language impairment. As a solution to this problem, it is proposed to examine children long before school, which in the long run will make it possible to quickly eliminate the problem of language training.

In the course of considering the basic tendencies in the formation and development of the system of inclusive education, it would be appropriate to present first of all the specifics of the incidence of persons who are subjects of inclusive education. Studying this issue will provide an opportunity to better develop and implement curricula in accordance with the conditions of inclusive education.

In the matter of the types of diseases that most often affect pupils with special educational needs, their detailed characteristics are presented in Figure 1. 
Figure 1. Types of diseases of pupils with special educational needs

\begin{tabular}{|c|c|c|}
\hline $\begin{array}{l}34 \% \text { of pupils need special } \\
\text { education due to disability }\end{array}$ & \multirow{5}{*}{ 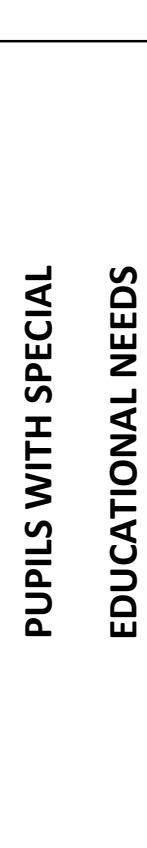 } & \multirow{2}{*}{$\begin{array}{c}6 \% \text { of pupils have psychological } \\
\text { underdevelopment, in the context } \\
\text { of which there is intellectual } \\
\text { disability }\end{array}$} \\
\hline $\begin{array}{l}\text { 19\% of pupils have speech } \\
\text { disturbance defects }\end{array}$ & & \\
\hline $\begin{array}{l}14 \% \text { of pupils have a disturbed } \\
\text { heart rhythm }\end{array}$ & & $\begin{array}{c}2 \% \text { of pupils have multiple } \\
\text { disabilities }\end{array}$ \\
\hline $\begin{array}{l}10 \% \text { of pupils suffer from autism } \\
\text { spectrum disorders }\end{array}$ & & $\begin{array}{c}1 \% \text { of pupils have orthopedic } \\
\text { disorders }\end{array}$ \\
\hline $\begin{array}{c}\text { 7\% of pupils have developmental } \\
\text { impairment }\end{array}$ & & $\begin{array}{l}1 \% \text { of pupils have hearing } \\
\text { impairments }\end{array}$ \\
\hline
\end{tabular}

Source: it has been compiled according to the investigations of National Center for Education Statistics, 2019.

The information presented in Figure 1, obtained on the example of studying the specifics of diseases of pupils with special educational needs in the United States, has revealed that the greatest need for the development of inclusive education is primarily necessary for students with disabilities. Based on foregoing, it can be assumed that in other countries the development of inclusive education is primarily aimed at ensuring appropriate learning conditions for students with disabilities.

According to data provided by the National Center for Education Statistics, in the USA during the 2017/2018 academic year, almost 7 million people received special education aged 3 to 21, which was $14 \%$ of the total number of all persons educated during this period.

Investigations prove that the specifics of the formation and development of the system of inclusive education are regulated by the provisions of international documents, which primarily provide the involvement of pupils with special educational needs in the educational process, who will receive special education together with healthy students.

Thus, in accordance with the provisions of the Convention on the Rights of Persons with Disabilities (CRPD), which was adopted in 2006 and entered into force in 2008, children, pupils with special educational needs receive the full right to receive inclusive education in an educational institution (including schools). The rights of pupils with special educational needs are equated to the rights of students who do not have any deviations. At the same time, students with special educational needs are enrolled in classes, in which ordinary students study.

With regard to the next stage of the algorithm for disclosing the practical principles of learning foreign languages at school under the conditions of an inclusive education, practical standards should be 
considered in this context; they should primarily be based on the curriculum for learning foreign languages by students with special educational needs under the conditions of an inclusive education.

Taking this into consideration, it should be noted that the educational process at school, which involves students, learning foreign languages, should be organized in accordance with World-Readiness Standards for Learning Languages. World-Readiness Standards for Learning Languages also determines the equality of all students in the learning process, that is, pupils with special educational needs have the same opportunity as ordinary students to learn foreign languages according to specially developed methods, implemented in practice.

It should be noted that the World-Readiness Standards for Learning Languages are developed and actively implemented in schools of the United States of America. Such experience of learning foreign languages by pupils with special educational needs at schools in the context of inclusive education, acquired by the United States of America, can be adopted by any country. This, in turn, will have a positive effect on the dynamics of success of students with special educational needs in the direction of learning foreign languages.

The third stage of the algorithm for disclosing the practical principles of learning foreign languages at school under the conditions of an inclusive education will center around presenting the basic programs that are currently being developed and implemented in practice, and the specifics of which are aimed at learning foreign languages by pupils with special educational needs under the conditions of an inclusive education.

For instance, in the United Kingdom, the government developed and implemented a program 20 years ago that required all students, especially those with special educational needs, to take a foreign language course. The scope of this program extended to such UK jurisdictions as England and Wales. According to the provisions of the program, the obligation to learn a foreign language was initially assigned to pupils aged 11 to 14 , including pupils with special educational needs. At the same time, the foreign language course was later extended to students under 16 , including students with special educational needs.

However, it is necessary to emphasize the importance of implementing information and interactive technologies in the system of inclusive education, especially when it comes to learning foreign languages by students with special educational needs. For instance, the Internet is a striking example of such technologies. The information that can be obtained on special Internet sites not only improves the level of teaching material to pupils with special educational needs, but also promotes better understanding of such material with high results in mastering a foreign language.

Consequently, currently there are many sources on the Internet from which teachers can get information about the features of presenting material to students with special educational needs. For instance, as follows:

1) Hilary McColl's website (Languageswithoutlimits.co.uk), one of the world's developers of language games that encourages pupils to learn foreign languages, including pupils with special educational needs, and the author of the scientific book "Modern Languages for All";

2) SENCO Forum, which is held in the UK and is designed to meet and communicate online with experienced teachers and professionals who provide training for pupils with special educational needs. SENCO Forum actively encourages new members to participate in discussions held on its basis, in order to share experiences in the organization of the educational process of students with special educational needs;

3) FLTeach, which has a number of useful links for teachers; they provide tips and techniques for presenting teaching materials in the process of learning foreign languages (including Chinese, Esperanto, French, German, Herben, Italian, Japanese, Latin, Persian, Portuguese, Russian, Spanish), thanks to which it 
is possible to increase efficiency of perception by pupils, including pupils with special educational needs, as well as new knowledge received in educational process;

4) Creative Education, which presents a number of courses that provide an opportunity to increase the effectiveness of knowledge acquisition during the study of a foreign language (foreign languages). Most of the courses, developed and offered by Creative Education, are aimed at an audience of pupils with special educational needs. In particular, one of the main courses should be singled out here - that is, the course Making MFL Accessible for Pupils with SEN, which can effectively adapt students with special educational needs to their perception and development of knowledge in the context of learning a foreign language.

As it has been mentioned above, the Making MFL Accessible for Pupils with SEN course, designed and implemented by Creative Education, is designed for MFL teachers and UK high school teachers who, in the process of teaching foreign languages to students at school, want to increase performance level of the subject of students with special educational needs.

The fourth stage of the algorithm for disclosing the practical principles of learning foreign languages at school under the conditions of an inclusive education will be a review of some training courses presented by the United Kingdom, which demonstrate the positive practice of learning foreign languages at school under the conditions of an inclusive education.

Following on from the outlined, investigations show that the government has developed and implemented a special course in the jurisdiction of the United Kingdom - Scotland, according to which the study of the language in Scotland is conducted as one to two ("Language Learning in Scotland: A 1+2 Approach"). The main goal of this course is to provide an opportunity for every student, including pupils with special educational needs, to learn modern language in the context of secondary school education. In addition, students, in particular pupils with special educational needs, have the right to learn the second modern language. "The Language Learning in Scotland: A $1+2$ Approach" program also provides a range of tips, guidance, tools and technologies for teachers to present learning materials in the context of teaching foreign languages of ordinary students and pupils with special educational needs.

Along with this, Oxford University Press (England) has developed and implemented an online course in which teachers can enhance their knowledge, develop skills and acquire abilities to teach pupils with special educational needs (including students with dyslexia, that is, not having ability to read texts) in the course of mastering foreign languages.

Thus, based on the considered practical features of learning foreign languages by pupils with special educational needs at school under the conditions of inclusive education in the leading highly developed countries of the world, it should be noted that the level of inclusive education in such countries is quite high. There is a high probability that pupils with special educational needs, in the course of learning foreign languages according to special curricula, will be able to find employment in the future, where knowledge of a foreign language will play an important role as a criterion for career and professional growth.

The viewpoint, determined according to the results of the investigation conducted, that specially developed curricula and teaching technologies for such students are of great importance for the growth of the level of success of pupils with special educational needs in mastering a foreign language, was confirmed by the results of the survey. The participants of the survey were directly pupils with special educational needs, teachers who directly teach such students, teachers' assistants who work directly with students with special educational needs. Students with special educational needs aged 8 to 16 took part in the survey. The survey was conducted on the basis of London School of Economics and Political Science (the UK) and the Integrative School Frankfurt (Germany). The results of a survey of students with special educational needs on how and what has helped them learn a foreign language showed that about $47 \%$ of respondents said that this was influenced by the availability of educational material according to their individual needs; $35 \%$ of respondents 
said that a special approach to learning, which was used by teachers and assistants has helped them achieve success, and $18 \%$ of respondents said that the use of modern educational technologies was of great importance for them. Almost $90 \%$ of teachers and more than $50 \%$ of teachers' assistants noted that the increase in the performance of students with special educational needs was due to the improvement of special curricula, which provide for the acquisition of a foreign language by students with special educational needs; only $8 \%$ of teachers and $43 \%$ of assistants said that this was due to the direct interest of such students, and $2 \%$ of teachers and $7 \%$ of assistants said that a special technology for inclusive education was of great help.

\section{DISCUSSION}

The practice of inclusive education has shown that recently pupils with special educational needs are actively involved in the educational process of educational institutions (including schools). This does not take into account the fact that they have the opportunity or do not have the opportunity to study, that is, are disabled. The above mentioned statements are currently governed by the provisions of numerous international instruments, among which the leading place is occupied by: 1) Convention on the Rights of Persons with Disabilities (CRPD), according to which students with special educational needs obtain a full right to receive inclusive education in an educational institution (including school); 2) World-Readiness Standards for Learning Languages. World-Readiness Standards for Learning Languages, which also determines the equality of all students in the educational process, that is, pupils with special educational needs on a par with ordinary students can learn foreign languages according to specially developed methods, implemented in educational practice.

It has been found that in the United Kingdom, in particular in the jurisdictions of England and Wales, there has been a program for more than 20 years, which stipulates that all students, including those with special educational needs, must take a foreign language course. In England, an online course has also been developed and implemented, on the basis of which teachers can enhance their knowledge, develop abilities and acquire skills to teach students with special educational needs (including students with dyslexia, that is those, not able to read texts) during their mastery of foreign languages. Along with this, there is a special course in Scotland, according to which language learning is conducted as one to two ("Language Learning in Scotland: A $1+2$ Approach"), that is, opportunities are provided for every student, including pupils with special educational needs, to learn a modern language in the context of secondary school education.

Investigations show that Finland also has been applying an active policy of involving students with special educational needs in secondary schools. In turn, German law also lays down rules for the inclusion of pupils with special educational needs in the general education system.

According to the results of the disclosure of practical features of learning foreign languages by pupils with special educational needs at school in the context of inclusive education in the leading highly developed countries of the world, it has been revealed that the level of inclusive education in such countries is quite high. At the same time, there is a high probability that pupils with special educational needs in the course of learning foreign languages according to the special curricula will be able to find employment in the future, where knowledge of a foreign language will play an important role as a criterion for career and professional growth.

\section{CONCLUSIONS}

The results of the disclosure of the features of learning foreign languages at school under the conditions of an inclusive education have shown that the specifics of the formation and development of the 
system of inclusive education is currently a very relevant issue. It is governed by the provisions of international documents which primarily provide the involvement of students with special educational needs in the educational process, who will receive special education together with healthy students (for instance, today many countries around the world adher to the provisions of international documents, prohibiting discrimination against the rights of persons with disabilities, in particular, the provisions of the Convention on the Rights of Persons with Disabilities and World-Readiness Standards for Learning Languages). The present study has proven that currently special curricula are being actively developed and implemented in practice, the specifics of which are aimed at learning foreign languages by students with special educational needs in an inclusive education.

In the course of studying the practical experience of the development of inclusive education in the UK, it has been found that such an experience of inclusive education, which is demonstrated by this country, can be a shining example for numerous countries that are currently actively involved in the formation and development of inclusive education. In addition, it has been revealed that the United Kingdom, which demonstrates a positive practice of learning foreign languages at school under the conditions of an inclusive environment, offers a variety of training courses, in which students with special educational needs can easily learn a foreign language.

It is proposed to use modern educational tools (including multisensory learning, audiobooks, mnemonic devices, etc.) in order to increase the understanding of educational material by students with special educational needs during the study of foreign languages) as well as develop a special curriculum, the main content of which should take into account the individual qualities and learning needs of students with special educational needs. At the same time, it is necessary to comprehensively equip classrooms with all necessary and modern tools and technologies of knowledge acquisition for better perception of educational material by students of inclusive classes.

Prospects for further research in the area outlined are center around disclosing and presenting the impact of curricula and courses, developed and implemented on the basis of inclusive education, the level of success and development of educational material by pupils with special educational needs.

\section{REFERENCES}

A 1+2 approach to modern languages. Education Scotland. National Improvement Hub, 2020. URL: https://education.gov.scot/improvement/learning-resources/a-1-plus-2-approach-to-modernlanguages\# (date of issue 23.09.2020).

Boa Sorte, P. (2020). Mark the correct answer? To whom? Deconstructing reading comprehension. Journal of Research and Knowledge Spreading, 1(1), 1-8.

Convention on the Rights of Persons with Disabilities (CRPD). United Nations, 2016. URL: https://www.un.org/development/desa/disabilities/convention-on-the-rights-of-persons-withdisabilities.html (date of issue 23.09.2020).

Dashti, E. (2020). Examining the relationship between unwillingness to translate and personality type of Iranian translation students. Journal of Research and Knowledge Spreading, 2020, 1(1), 1-10.

DeFalco, L. (2011). Integrating the Secondary School Foreign Language Classroom through Multiple Learning Activities. Non-Journal, 30 p. URL: https://eric.ed.gov/?id=ED521246 (date of issue 23.09.2020).

English As A Second Language (ESL) For Inclusive Education. The Progressive Teacher, 2020. URL: http://www.progressiveteacher.in/english-as-a-second-language-esl-for-inclusive-education/ (date of issue 23.09.2020). 
Ebrahimi, M. A. (2020). Cultural value of translation of proverbs and synopsis. Journal of Research and Knowledge Spreading, 1(1), 1-10.

Florian, L. (2017). Teacher Education for the Changing Demographics of Schooling: Inclusive Education for Each and Every Learner. Teacher Education for the Changing Demographics of Schooling. Inclusive Learning and Educational Equity, 2, 9-20. URL: https://link.springer.com/chapter/10.1007/978-3319-54389-5_2 (date of issue 23.09.2020) DOI:10.1007/978-3-319-54389-5_2.

Florian, L., Young, K., Rouse, M. (2010). Preparing teachers for inclusive and diverse educational environments: studying curricular reform in an initial teacher education course. International Journal $\begin{array}{lllll}\text { of Inclusive } & \text { education, } & \text { 709-722. } & \text { URL: }\end{array}$ https://abdn.pure.elsevier.com/en/publications/preparing-teachers-for-inclusive-and-diverseeducational-environm (date of issue 23.09.2020) DOI:10.1080/13603111003778536.

Florian, L., Linklater, H. (2010). Preparing teachers for inclusive education: using inclusive pedagogy to enhance teaching and learning for all. Cambridge Journal of Education, 40 (4), 369-386. URL: https://www.tandfonline.com/doi/abs/10.1080/0305764X.2010.526588 (date of issue 23.09.2020) DOI:10.1080/0305764X.2010.526588.

Fullagar, S. (2019). A physical cultural studies perspective on physical (in)activity and health inequalities: the biopolitics of body practices and embodied movement. Revista Tempos e Espaços em Educação, 12(28), 63-76.

Germany's inclusive education, language support leave fewer foreign children in special ed. Mainichi, 2019. URL: https://mainichi.jp/english/articles/20191121/p2a/00m/0fe/014000c (date of issue 23.09.2020).

Hilary McColl - Publications. Languages without Limits, 2016. URL: https://www.languageswithoutlimits.co.uk/hm_publications.html (date of issue 23.09.2020).

Hildebrandt, S. A. (2020). Universal Design for Instruction: Inclusive Teaching Practices for the World Language Classroom. Differentiation in Support of Diversity. URL: https://uageeducator.org/actfl/february_march_2020/Mobile (date of issue 23.09.2020).

Hockly, N. (2016). Special educational needs and technology in language learning. ELT Journal, 70 (3), 332-338.

Inclusive Practices in England Language Teaching. Oxford University Press, 2020. URL: https://elt.oup.com/feature/global/expert/inclusive?cc=ua\&selLanguage=uk (date of issue 23.09.2020).

Languages. Creative Education, 2020. URL: https://www.creativeeducation.co.uk/subject/languages (date of issue 23.09.2020).

MacAskill, M. (2016). Modern languages and inclusion in the context of Scotland's 1+2 language policy. Scottish Languages Review, 31, 1-8.

Making MFL Accessible for Pupils with SEN. Creative Education, 2020. URL: https://www.creativeeducation.co.uk/course/7896 (date of issue 23.09.2020).

McColl, H. (2005). Foreign language learning and inclusion: Who? Why? What? - and How? Support for $\begin{array}{llll}\text { Learning, } & 20 & \text { (3), 103-108. URL: }\end{array}$ https://www.researchgate.net/publication/227663164_Foreign_language_learning_and_inclusion_ Who_Why_What-_and_How (date of issue 23.09.2020) DOI:10.1111/j.0268-2141.2005.00372.x. 
McFarland, J., Hussar, B., Zhang, J., Wang, X., Wang, K., Hein, S., Diliberti, M., Cataldi, E. F., Mann, F. B. Barmer, A. (2019). The Condition of Education 2019. National Center for Education Statistics, 396 p.

Medrado, B. P., Mello, D., Tonelli, J. R. A. (2019). Inclusive practices and policies in language teacher education courses. DELTA: Documentação de Estudos em Lingüística Teórica e Aplicada, 35 (3). URL: https://www.scielo.br/scielo.php?script=sci_arttext\&pid=S0102-44502019000300406 (date of issue 23.09.2020) DOI:10.1590/1678-460x2019350307.

Miesera, S., DeVries, J. M., Jungjohann, J., Gebhardt, M. (2018). Correlation between attitudes, concerns, self-efficacy and teaching intentions in inclusive education evidence from German pre-service teachers using international scales. Journal of Research in Special Educational Needs, 19 (2). URL: https://onlinelibrary.wiley.com/doi/abs/10.1111/1471-3802.12432 (date of issue 23.09.2020) DOI:10.1111/1471-3802.12432.

Mitchell, D. (2008). What Really Works in Special and Inclusive Education: Using evidence-based teaching strategies. $\quad$ Routledge, $253 \quad$ p. URL: https://www.academia.edu/37967852/David_Mitchell_2008_What_really_Works_in_Using_Eviden ce_based_Teaching_Strategy (date of issue 23.09.2020).

Motschenbacher, H. (2016). Inclusion and foreign language education. ITL - International Journal of Applied Linguistics, 167: 2, 159-189. URL: https://benjamins.com/catalog/itl.167.2.03mot (date of issue 23.09.2020) DOI:10.1075/itl.167.2.03mot.

Pokrivcakova, S. (2015). Teaching foreign languages to learners with special educational needs in Slovakia. Teaching Foreign Languages to Learners with Special Educational Needs: e-textbook for foreign language teachers. Nitra: Constantine the Philosopher University, 128 p. URL: https://www.researchgate.net/publication/285593135_Teaching_foreign_languages_to_learners_ with_special_educational_needs_in_Slovakia (date of issue 23.09.2020) DOI:10.17846/SEN.2015.728.

Special educational needs in England. GOV.UK, 2020. URL: https://explore-educationstatistics.service.gov.uk/find-statistics/special-educational-needs-in-england\#releaseHeadlinestables (date of issue 23.09.2020).

Special Needs and Inclusive Education in Germany. German education server, 2019. URL: https://www.eduserver.de/Special-needs-and-Inclusive-Education-Germany--4523-en.html (date of issue 23.09.2020).

Striving to enhance the individuality and development of each student. Global Education Park Finland, 2017. URL: https://www.globaleducationparkfinland.fi/future-skills/inclusive-education-special-needs (date of issue 23.09.2020).

Troeva, B. (2016). Inclusive Education in Foreign Language Teaching: What is the First Step to Make it Work? Yubileen godishnik na departament "Anglitsistika», 29-41. URL: https://publishinghouse.nbu.bg/bg/elektronni-izdaniq/periodika/jubileen-godishnik-na-departament-anglicistika2016 (date of issue 23.09.2020).

Web Links for Language Teachers. FLTeach, 2017. URL: https://web.cortland.edu/flteach/flteach-res.html (date of issue 23.09.2020).

Wilson, D. (2019). Language learning and students with special educational needs. URL: http://ppli.ie/wpcontent/uploads/2019/02/David-Wilson-Specialeducationalneeds.com_.pdf. (date of issue 23.09.2020). 
Who is the Senco Forum for? SENCOFORUM, 2020. URL: https://www.sencoforum.com/ (date of issue 23.09.2020).

World-Readiness Standards for Learning Languages. ACTFL. URL: https://www.actfl.org/resources/worldreadiness-standards-learning-languages (date of issue 23.09.2020).

\section{$\underline{\text { ABOUT THE AUTHORS }}$}

\section{Chernysh V. Valentyna}

Doctor Hab. of Pedagogical Sciences, Professor, Head of Department, Faculty of Roman Philology and Translation, Department of Foreign Languages Methodology Teaching and Information and Communication Technologies. Kyiv National Linguistic University. Kyiv, Ukraine.

E-mail: kseniia.tsy@i.ua

ORCID: https://orcid.org/0000-0002-5457-5024

\section{Navolska I. Halyna}

Candidate of Pedagogical Sciences, Associate Professor, Faculty of Foreign Languages, Department of Foreign Languages. Ternopil Volodymyr Hnatiuk National Pedagogical University.Ternopil, Ukraine.

E-mail: larkal1835@gmail.com

ORCID: https://orcid.org/0000-0003-4196-0123

\section{Rusavska O. Olha}

Associate Professor, Candidate of Philological Sciences, English Language Teacher, Marine Transportation and Technologies. National university "Odessa Maritime Academy". Odessa, Ukraine.

E-mail: romanova-ania@ukr.net

ORCID: https://orcid.org/0000-0003-1513-1540

\section{Ryabokin Nataliia}

Candidate of Philological Sciences, Head of the Department, Associate Professor, Department of Philology and Social Sciences and Humanities. Poltava Institute of Economics and Law. Poltava, Ukraine. E-mail: nataliazai50@gmail.com

ORCID: https://orcid.org/0000-0001-5950-8798

\section{Paustovska V. Marianna}

Candidate of Pedagogical Sciences, Associate Professor, School of Translation Studies, Korunets Department of English and German Philology and Translation. Kyiv National Linguistic University. Kyiv, Ukraine.

E-mail: zaitsevaalla923@gmail.com

ORCID: https://orcid.org/0000-0002-1228-2178 